\title{
Raíces y permanencias de la partidocracia uruguaya
}

Gerardo Caetano

y José P. Rilla

CLAEH

LA HIPÓTESIS Y SU TEORÍA

Historia y política: algunos usos recíprocos

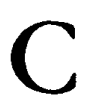

ualquier observador del acontecer uruguayo podría reparar sin mayores dificultades en que historia y política se influyen aqui recíprocamente, y que en el juego de los intercambios, una es a menudo un recurso de la otra.

Veamos la primera dirección de este intercambio, la de la historia como recurso de la actividad política. Si bien se mira, es probable que no hubiera podido ser de otra forma en un país donde la vida política acusa fuertes permanencias y donde sus actores centrales, los partidos políticos, han mostrado gran estabilidad aun en el marco de situaciones de cambio. La acción política en el Uruguay tiene gran ocasión de presentarse como una continuidad, por lo que la remisión al pasado se vuelve ineludible. La innovación, como quiebra de esa continuidad, es en general sancionada, entre otras razones, cuando no encuentra referencias en el pasado, cuando no puede demostrar "genealogías".

Tómense como indicadores los momentos de consolidación de un orden político, los momentos de crisis y sobre todo los fundacionales, y se verá con qué facilidad el discurso político de los actores remitió al pasado y buscó su ascendencia. Se verá, por ejemplo, que los ímpetus moder- 
nizantes de los batllismos siempre se recostaron, al menos en teoría, en el primer batllismo; que la intransigencia democrática del nacionalismo fue ofrecida como fruto de una acumulación histórica y coherente, como actualización de una señal de identidad construida en el siglo XIX; y que la programática y aun la acción de la izquierda se instalaron en la trama social y clasista de la política y refirieron a las rupturas revolucionarias de la edad contemporánea, demarcando a su vez una nueva tradición.

Se dirá que es una forma conservadora de hacer la política (aunque la política siempre se hace desde algún "lugar") y que, como tal, requiere de la historia, $O$ al menos, de una cierta interpretación de la misma. Paradojalmente, esto ni por asomo significa que el uso y abuso que del pasado hacen nuestros partidos reporte a esta sociedad un cabal conocimiento del mismo. Se trata, en todo caso, de un impor. tante saber social demasiado instrumentalizado por los actores y notoriamente menguado en sus potencialidades críticas.

La segunda dirección de este intercambio nos habla de la política como recurso de la historia, o más claramente, como condicionamiento de la historiografía. No parece difícil advertir -y algún día será necesario registrarlo en forma casuística- que la historia siempre se escribe desde un presente -político en este caso-y que son las pulsaciones de la actualidad las que dirigen las preguntas hacia el pasado. La coyuntura asedia a la estructura y, gracias a la política, la historia es siem. pre una inquisición interesada y exi- gente, pero también por ello una inquisición de objetos muy variables.

Por último, una dimensión más académica de los intercambios, aunque no tan discernible de las anteriores como las apariencias podrían sugerir, es la que hace del pasado reconstruido por los historiadores un campo empírico cada vez más recurrido por la ciencia y la filosofia políticas. No es de otra materia que se constituyen sus ejercicios de precaria "experimentación". Es en cambio más reciente y esporádico -pero igualmente rendidor- el servicio que la teoría política presta a la indagación histórica. Con todas las cautelas del caso, entre las cuales no son de menor relevancia la preservación de la globalidad de los enfoques y la capacidad de ser comprendida por el hombre común -mérito este sí casi exclusivo de la historia en el Uruguay-, hoy resulta insostenible la posibilidad de historiar la política sin el marco y el acicate de la teoría política, por más rudimentaria y disimulada que ella sea.

\section{El retorno de la política}

De las paradojas que median entre la peripecia social y su historia, tal vez sea el rezago de la historia política lo que más sorprenda en este medio siglo en el que la política ha cobrado tanta primacía en la vida social contemporánea. Es probable que el desdén por la historia política le deba mucho a la orientación que tomaron algunos historiadores fanceses de la entreguerra, los que variablemente influidos por el marxismo reaccionaron sistemáticamente contra el 
sofocón que les significaba el acopio positivista, aquel "jadeo factual" que exprimía la superficie histórica y desaprovechaba una impresionante masa de acontecimientos.

La lista de cargos a aquella forma de historiar lo político es abultada: psicológica e incondicionada, de elites dirigentes y dominantes; localista y parroquial; "asocial"; cualitativa, epicéntrica y narrativa; particularista y sin marcos de comparación; ingenuamente ideológica, institucionalista y juridicista; moldeadora, al fin y al cabo como toda historia, de las ideas de los hombres acerca de su pasado.

El descarte de la dimensión social y económica resultó sin duda inhibitorio de algunos interrogantes a los que el presente, desde el cual se escribe la historia, debe obligar. Así, la memoria parecía más un registro que una construcción de quien observa. De todas formas el saldo no es ruinoso, pues la cuestión ha terminado por residir en qué preguntar a los hechos tan traba. josamente exhumados.

La reacción antipositivista reportó a su vez otros descartes: suponía que bastaba indagar en las raíces y en las bases de los fenómenos, que lo demás, lo no económico ni social, gruesamente delimitados, eran apenas un reflejo, un epifenómeno. Lo susceptible de acontecer se confundió entonces con el acontecimiento y, consecuentemente, la debilidad metodológica de "los tradicionales", con el objeto de su indagatoria.

Frente a la vieja historia, las jóvenes ciencias políticas y sociológicas saltaron hacia adelante $-a$ veces sin mirar atrás- y desplegaron categorias, mar- cos teóricos e instrumentos de análisis que comenzaron a dar cuenta y explicación de lo político. También el marxismo ha hurgado en la idea de lo político como acción irreductible a la lucha de clases y generador de constelaciones específicas y relativamente autosustentadas. Como podría resultar previsible, la historia se encaminó hacia las preguntas que de las demás ciencias surgen: la política ha vuelto a ella.

El retorno de la política en América Latina parece asociarse a una doble coyuntura. La coyuntura bistórica de las últimas décadas, signada por los regímenes autoritarios de la región, permitió y exigió un vuelco de las líneas de reflexión hacia el tema de la democracia. Si en los años 60 fueron los dilemas del "desarrollo", la "dependencia" y la "revolución" los que más ocuparon la atención académica, la cancelación y posterior recuperación de las libertades, el desalojo de la política del espacio público y la actual "recolonización", obligaron a poner el acento en lo político, en especial desde una renovada perspectiva democrática. Lo que aparenta ser una "reflexión sobre lo obvio", como decía Real de Azúa, ló que es una búsqueda desde el derrumibe, se convierte así en el origen de nuevas y operativas incursiones en el conocimiento de la sociedad. En otras palabras, la clausura de la vida política durante las pasadas dictaduras nos impele, en medio de la ansiedad y la desorientación, a "comen. zar por el principio": ¿Qué stgnifica bacer politica?1

1 Tal es el revelador título de un texto editado y compilado por Lechener, ¿Que?, 1982. 
Por su parte, la coyuntura que podríamos llamar científica está obviamente marcada por similares avatares. Pero su especificidad radica en que el curso de las ciencias sociales puede mostrar más soltura respecto a la demanda política, aun en el caso de verse urgida por ella. Este retorno de la política, de la mano del retorno de la democracia, aceleró la crisis de diversos paradigmas, rebajó la estatura de las interpretaciones globalizadoras y suspendió -tal vez precariamentealgunas claves teóricas del conocimiento acumulado.

\section{Desafíos de una nueva bistoria política}

La historiografia uruguaya se debe aún a buen trecho de ese camino de re. torno. La crisis del modelo piveliano ${ }^{2}$

\footnotetext{
2 Cuando hablamos de "modelo piveliano" nos referimos a la matriz interpretativa de la historia uruguaya que surge de la vasta producción del profesor Juan E. Pivel Devoto (1910), sin duda uno de los mayores historiadores del país. A pesar de que resulta dificil reconocerle discípulos directos, su profusa obra historiografica ya sea como autor de obras como Ratces, 1942, o Historia, 1945, entre otras muchas, ya como principal promotor de colecciones como Clásicos Uruguayos o el monumental Archivo Artigas, incluso como director del Museo Histórico Nacional durante más de cuatro décadas o como profesor de Historia Nacional y Americana en el Instituto de Profesores Artigas, etcétera) ha marcado a varias generaciones de profesores e historiadores uruguayos. Entre las notas más distintivas de lo que llamamos "modelo piveliano" podrían citarse: una fuerte postura nacionalista en su intepretación de los orígenes de la independencia uruguaya; un persistente apego a un enfoque tradicional de historia política, centrado casi exclusivamente en el análisis de la trayectoria de los partidos "tradi-
}

fue sin duda acelerada por los relevantes avances que desde hace veinte años se han concentrado en historia económica y social. Pero adviértanse, por ejemplo, que la sagaz indagatoria del pasado colonial y artiguista de Lucía Sala, Julio Rodríguez y Nelson de la Torre, o la impresionante Historia rural de Barrán y Nahum, si bien han delimitado un nuevo universo historiográfico, no han generado más estudios propiamente políticos que los que tales obras también contienen.

Poco se ha escrito acerca de la política durante el ciclo artiguista o la cisplatina; menos aún sobre el resto del siglo xIX. El batllismo, en cambio, parece haber orientado los estudios hacia la política, pero la deuda decimonónica puede hacernos caer en una suerte de reduccionismo batllicentrista que menoscabe la suerte de una historia que busca cambios y permanencias de la vida social.

Debe observase, sin embargo, que la última colección de Barrán y Nahum, Batlle, los estancieros y el imperio británico, está significativamente

cionales" uruguayos (con una clara devaluación de las experiencias terceristas, en particular de la izquierda) y con una escasa o nula referencia a la acción de otros actores sociales (sindicatos, organizaciones empresariales, etcétera); un enfasis reiterado en los estudios de periodos alejados lo más posible del presente, con una particular dedicación a las indagatorias sobre el siglo Xx uruguayo, marco cronologico sobre el que discurren la mayoría de sus traba. jos más importantes; una fuerte reivindicación de independencia disciplinaria, con la casi inexistencia de diálogo con otras ciencias sociales y con un manejo bastante tradicional del oficio historiográfico (tanto en los marcos teóricometodológicos como en lo que concierne al aspecto heuristico empleado); etcétera. 
tensionada por la indagación en lo político: inaturaleza del tema?, ipreguntas urgidas por el presente? Tal vez ambas cosas. Los ocho tomos recién culminados son ricos en nuevas discriminaciones temáticas acerca de la política uruguaya (autonomía relativa del Estado, primacías políticas y sociales, inserción regional de las adhesiones electorales, para citar sólo algunas); en sugerencias teóricas y metodológicas; en contenido polémico pero siempre pertinente; como la $\mathrm{His}$ toria rural, remite al país todo y anida "otras historias", las que, complementarias o divergentes, requieren del concursó de sus dilemas a veces mejor planteados que resueltos.

Sin el ánimo de diseñar un programa de investigación, conviene tener presente que la historia política uruguaya debe ser aún escrita en im. portantes tramos y que, para el siglo $\mathrm{XIX}$, debería ser reescrita. Y esto último, que cuenta con los avances ya anotados en materia social y económica, todavía podría emprenderse a partir de la masa fáctica lograda desde la historiografia tradicional. El problema central, otra vez, reside mucho más en las preguntas que hacemos al repertorio, que en el repertorio mismo de los hechos.

Es sabido que la periodificación en historia es una operación significativa . que denuncia criterios de fondo. A pesar de algunos avances importantes, ${ }^{3}$

3 Puede registrarse, por ejemplo, la periodificación implicada en los manuales preuniversitarios de la Historia Uruguaya de la Banda Oriental: Castellanos, Cisplatina, 1975; Barrán, Apogeo, 1975; Méndez Vives, Uruguay, 1975; Nahum, Epoca, 1975; Nahum, Crists, 1975. Car- el pasado político uruguayo sigue siendo observado -sobre todo en las aulas y en la prensa- en función de claves político-institucionales. Tras la excelencia de sus "raíces coloniales", Pivel Devoto nos muestra esta secuen. cia: el nacimiento de la república; $\mathbf{R i -}$ vera, Oribe y la Guerra Grande; los "intentos de consolidación nacional" entre 1852 y 1875 ; y finalmente la tríada "militarismo, civilismo, estatismo". 4

Pero si la historia política es; entre otras cosas, una indagación del poder, de su composición, su funcionamiento y su distribución, y todo ello en la dimensión temporal, se nos imponen entonces otros com. promisos teóricos y temáticos. No es desdeñable, por ejemplo, el imperativo de historiar a la política en el

los Real de Azúa, cal vez el crítico más activamente demoledor del modelo piveliano, proponía en 1969 una demarcación política más envolvente, aunque también más valorativa y hasta metafórica: La precaria estabilización y su quiebra (1820-1838); La Guerra Grande $y$ su proemio (1838-1851); Tiempos revueltos, tiempos de todo (1851-1865); Militarismo incipiente y militarismo formal (1865-1886); "Civilismo" y oligarquía (1886-1903); Un batllismo y un país en forma (1903-1915); Trámite y usura (1915-1933); El golpe de Estado y sus consecuencias (1933-1938); La "recuperación de-

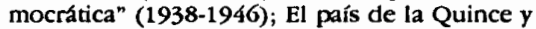
el segundo colegiado (1946-1958); y los ocho años blancos y el presente (1958-1968). Véase La historia política, Enciclopedia, t. I, 1969.

( Pivel Devoto, en el tomo il de su obra Partidos, 1943, ordeno la historia de nuestras colectividades en la segunda mitad del siglo xx en los siguientes tramos en los que intercalo capítulos referidos a la legislación electoral: 1 . La inexistencia de los partidos (1865-1872); II. Los partidos de principios (1872-1875); III. El militarisn:o (1875-1880) y N. El milicarismo (1875-1894); v.. La libertad política (1895-1897). 


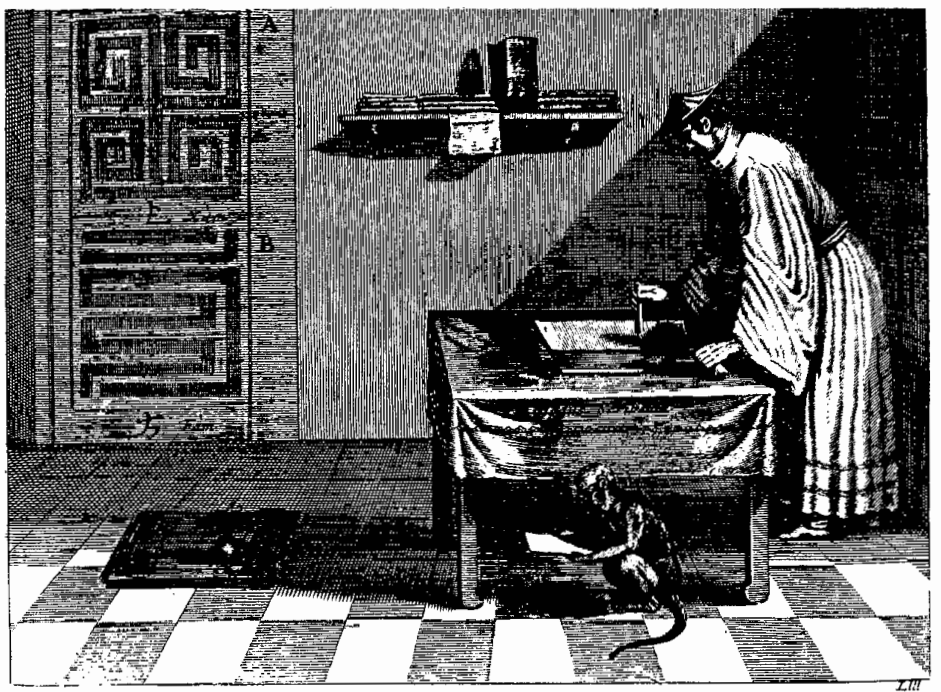

marco de la larga duración. Las inflexiones más o menos drásticas del pasado nacional generan "ilusiones ópticas": las revoluciones, las rupturas institucionales, las embestidas reformistas -para mencionar tres casos- nos ocultan las permanencias y transforman todo en "novedad". Parece, en efecto, que la periodificación fuera más un rasgo del objeto que un aporte del sujeto.

En la cuantificación de lo político hay también un camino. Allí se ha avanzado en forma significativa en el estudio de algunos procesos pero escasean las series preparadas a tal efecto y sobre todo la formación teórica y metodológica de nuestros investigadores. Conviene incluso recordar lo obvio: no sólo se debe y se puede cuantificar lo electoral; el análisis de tex- tos es riesgosamente útil y el personal político, burocrático, empresarial son territorios apenas roturados.

Mejores preguntas, larga duración, cuantificación pueden resultar entonces buenas vías de llegada a la historia política y a su reescritura. Tómese por válida la centralidad que lo partidario presenta en la política uruguaya y el repertorio de temas y enfoques a profundizar, inaugurar o imaginar resultará abultado:

a) el tema de la ideología y las demás constelaciones intelectuales, el lote de símbolos, valores, mitos y afectos que supuso y supone la acción partidaria; la construcción de tradiciones políticas y parapolíticas de los partidos tradicionales y de los llamados partidos "de ideas"; la famosa tarea de reconstrucción ideológica del mismo pa- 
sado nacional a partir de las referencias partidarias;

b) la problemática referida a la conducción (caudillo, líder, colegio, jefe de aparato, tecnócrata, parlamentario, intelectual orgánico, tribuno, "juntavotos") y a los aparatos partidarios (cuadros intermedios, militantes, etcétera);

c) las generaciones y los partidos, la diferenciación etaria de los votantes, las trayectorias del militante y de las elites partidarias;

d) la formación y el funcionamiento electoral como espacios de dilucidación de pleitos cruciales; los cambios de la lealtad partidaria; la normativa electoral y el comportamiento electoral; la relación clientelística;

e) las formas de la socialización política y su impacto en los partidos; las funciones "no políticas" de los partidos; educación, familia y reproducción de lo partidario; partidos, medios y formas de comunicación;

f) la coparticipación y el gobierno, sus logros y retardos; la democracia como construcción;

g) los partidos uruguayos y el mundo exterior; las vinculaciones orgánicas e inorgánicas (federales y unitarios, presencias, imperiales, guerras regionales y mundiales, partidos internacionalistas, etc.); las diferencias interpartidarias y el "fondo común", etcétera.

\section{UNA POLÍTICA DE PARTIDOS}

\section{Marco de referencia}

Entre las claves más señaladas para comprender la intrincada política uru- guaya, ocupa un lugar destacado la referencia a su condición predominante -aunque no exclusiva-de política de partidos. En efecto, esa centralidad de los partidos uruguayos como actores políticos dominantes constituye una línea de larga duración de nuestra historia y una clave configuradora de nuestra política. Desde la etapa fundacional del Estado y la sociedad uruguayos, hasta el proceso contemporáneo de la dictadura y la transición democrática, no resulta difícil, en verdad, hallar procesos y elementos confirmatorios de ese fenómeno manifiesto de la partidarización.

Por cierto que este carácter de estabilidad y firmeza de los partidos otorga a la historia política uruguaya un nuevo elemento de singularidad respecto a las otras repúblicas del continente. En efecto, la centralidad del papel de los partidos dentro del sistema político constituye un fenómeno altamente atípico en la mayoría de los países de América Latina, habituados por lo general al predominio de otros actores en la tramitación de las políticas estatales y en los ámbitos decisorios. 5

La relevancia de los partidos en la política se vincula claramente con otras peculiaridades de la sociedad uruguaya: una estratificación social que revela históricamente bajos niveles de tensiones interclasistas, un

S Cfr. Thompson, Partidos, 1987. En esta perspectiva, sin embargo, cabría preguntarse acerca de la relevancia de los partidos en otros países latinoamericanos, como Honduras, Colombia, Chile y Costa Rica, lo que a nuestro juicio no obsta para ratificar la singularidad del caso uruguayo. 
Estado tradicionalmente inclusivo y relativamente autónomo, un elenco político con fuertes índices de adensamiento grupal y persistencia, una cultura política mesocrática y fuertemente referida a la postulación de una "república de ciudadanos", entre otros rasgos no menos relevantes. Advirtamos de inmediato que en este listado sumario de fenómenos y rasgos de la historia uruguaya de larga duración relacionados con la centralidad de los partidos, se entremezclan factores de muy diversa índole y significación. En algunos de ellos se percibe más nítidamente una referencia de tipo causal; en otros predomina la condición de efecto; muchas veces se perfila una simbiosis entre ambas relaciones. Por ejemplo, el tipo de estratificación social tradicional del Uruguay ha favorecido y aun propiciado el éxito de una convocatoria ciudadana, de corte policlasista, tan propia de los partidos; a su vez, en la compleja trayectoria del Estado uruguayo es posible rastrear tanto orígenes como consecuencias de la centralidad partidaria.

De este modo, no se pueden comprender cabalmente las raíces de esta "política de partidos" sin referirse al marco más general de las relaciones entre Estado y sociedad o a las formas peculiares en que discurre el fenómeno de la cultura política en el Uruguay.

Entre las múltiples traducciones que tiene el predominio de los partidos en el espectro tradicional de los actores de la política uruguaya, tal vez pocas adquieren la efectiva trascendencia del espacio central ocupado en la historia uruguaya por el arbitraje electoral como referencia incluso configuradora de todo el sistema político. Cualquier vistazo sumario que se haga sobre la evolución política no puede sino destacar, como rasgo estructural, el peso formidable de la tradición electoralista sobre el conjunto de los actores políticos. Esa fuerte configuración electoralista del sistema político es una característica que por otra parte ya tiene sus años en el país. Data efectivamente desde comienzos de siglo, momento a partir del cual se evidencian muy altos índices de participación electoral ${ }^{6}$ y se produce una espectacular aceleración en el crecimiento del electorado. 7

Esa referencia electoralista de nuestra "política de partidos" guarda asimismo relación con el papel decisorio que muchos actos comiciales han tenido en la historia del país. Así, por ejemplo, la derrota del primer batllismo en 1916, que propicio la política del "alto" a las reformas, o la espectacular victoria nacionalista de 1958, que impulsó un cambio de rumbo categórico en la historia política del país. Así también lo ocurrido con los militares uruguayos du-

6 En los comicios nacionales de 1930 para la elección de presidente de la república, miembros del Consejo Nacional de Administración y colegios electorales en cinco departamentos, afirmaron que la participacion llego al 80.05\% del total de habilitados, siendo estos últimos aproximadamente el $\mathbf{9 1 \%}$ sobre el máximo posible de personas que podrían revestir en aquel momento condición de ciudadanos. Para un seguimiento de la evolución de la participación electoral, cfr. Rial, Elecciones, 1984.

7 Sólo entre 1905 y 1931 (apenas 26 anos y aun antes de la concesión de los derechos políticos femeninos), el electorado creció en un 668.4\%. Cfr: Frega, Pluralismo, 1987. 
rante su hegemonía en el gobierno en los últimos años, quienes en el momento en que buscaban una legitimación para sus planes fundacionales, no dudaron en procurarla por la via plebiscitaria en 1980. En este contexto pudo ser un grave error prescindir de la mediación de los partidos (incluso de los tradicionales). En tal sentido y como también lo probaría el reciente referéndum, el periodo dictatorial y la transición democrática no pudieron enajenarse a esa regla tan uruguaya de dirimir los pleitos cruciales en el escenario electoral.

\section{Tareas $y$ transferencias partidarias}

Política de partidos y ciudadanos, política amplia y profundamente electoralizada. Pero, ¿cuáles fueron las raíces y las razones de este rasgo estructural? Pasemos una rápida revista a algunas de ellas.

En primer término, resulta esclarecedor reparar en el extenso repertorio de funciones y tareas de muy diversa indole que han desempeñado nuestros partidos. Es en el marco de esa perspectiva histórica como puede corroborarsé de modo más enfático la pertinencia de la consideración sistémica de los partidos uruguayos. Si en la observación de nuestra práctica política cotidiana aparecen rasgos muy recurrentes que contribuyen a reafirmar la idea de partidos que interactúan de modo casi permanente y que operan complementariamente en múltiples aspectos, es en el reconocimiento de sus faenas comunes que su sistema de interacciones múltiples ad- quiere perfiles más nítidos y estables. ${ }^{8}$

Es así que en el marco de un sistema y en la larga duración se descubren prioritariamente en los partidos los orígenes de ciertas prácticas decisivas que llegaron a generalizarse más allá del nivel estrictamente político en la sociedad uruguaya. Ese cumplimiento relativamente exitoso de múltiples tareas -de envergadura no menor, como veremos- se insinúa como labor mancomunada de los partidos, más allá de la conflictividad inherente de sus interrelaciones. Mencionemos a título de ejemplos: la lenta pero firme superación de las tendencias excluyentes respecto de la participación política de las masas (cuyas primeras raices hay que rastrear efectivamente en el rico siglo XIX uruguayo, criterio que polemiza con la tesis extendida de la democracia uruguaya como "invención moderna" del 900); la incorporación del inmigrante a la actividad política y aun en su plena "nacionalización" (función decisiva en una sociedad aluvional y expuesta como la uruguaya, en la que cupo a los partidos un papel tan fundamental como pionero); el desenvolvimiento y progresivo refinamiento, en ocasiones hasta alcanzar barroquismo, de fórmulas de coparticipación en el ejercicio del poder con sugestivos y tempranos equilibrios poliárquicos (proceso dialéctico y complejo de fragua democrática en el que también operaron elementos $\rightarrow$ residuos resistentes- del federalismo y en el que resultaron cuestio-

8 Para el tema de la pertinencia de la consideración sistémica de los partidos uruguayos, cfr. Pérez, "Partidos", 1984. 
nados ámbitos y elites no sólo políticos sino también culturales, sociales y económicos); el involucramiento "ciudadano" de la casi totalidad de la población, aun con las "trampas" múltiples del sistema tradicional (ley de lemas, clientelismo, desmovilización en la sociedad uruguaya al punto de hacerlo casi sinónimo del "ser nacional"), proceso de larga duración que aparece en la historia de las divisas en el siglo XIX, en la explosiva electoralización de la sociedad uruguaya de las primeras décadas de este, en las visibles-aunque también menguadas-resistencias de sectores de la sociedad civil ante el decaimiento de las instituciones en 1973 y en el más amplio y vigoroso enfrentamiento a los intentos fundacionales antidemocráticos durante el final del proceso dictatorial; entre otras.

En el cumplimiento de estas y otras tareas, los partidos uruguayos (todos, no sólo los tradicionales) no llegaron a alterar de modo decisivo sus "pactos fundacionales" y su esquema organizativo, haciendo fracasar muchas veces tentaciones corporativistas e intentonas golpistas, las que, si siempre encontraron apoyos en los partidos, casi nunca llegaron a hegemonizarlos $y$, antes bien, despertaron fuertes resistencias dentro de ellos. No es casual entonces que, en la génesis de los distintos procesos dictatoriales por los que ha atravesado la historia uruguaya (comparativamente escasos respecto a los demás países de América Latina), casi siempre surja como dato fundamental entre sus antecedentes la crisis de los partidos o su inhibición coyuntural en el cumplimiento de algunas de sus funciones tradicionales.
Por cierto que la centralidad de los partidos no sólo ha operado en sentido favorable respecto del destino y de la trama de la política uruguaya. El hecho de que muchos de los vicios y desequilibrios presentes en la vida política cotidiana de los uruguayos hayan sido transferidos fundamentalmente desde los partidos (para alcanzar luego, y tal vez por ello, una relevancia primerísima en el resto del sistema políticò), constituye un nuevo elemento que reafirma su carácter de actores políticos dominantes. En el marco de ese registro mencionemos a título indicativo: la extensión del clientelismo como una base de sustentación de la expansión del Estado, tributario de una configuración de signo particularista, escasamente funcional para el papel de dinamizador y centro organizador de una economía de crisis endémica; la desarticulación ideológica y organizativa que provocó a menudo la emergencia de políticas públicas erráticas y claramente desprovistas de un proyecto nacional verdadero; la captura de lo social organizado por lo partidario, que redundó con frecuencia en el bloqueo de impulsos endógenos y desarrollos autónomos de la sociedad civil y que por eso mismo generó un çierto empobrecimiento y encorsetamiento de la cultura política general del país (sin desmedro del registro también señalado de una sociedad uruguaya con bloqueos intrínsecos y no transferidos desde la política o los partidos, con la extensión de una red intrincada de vetos recíprocos y restas 
de impulsos auténticamente transformadores); entre otros.

\section{Una "política de permanencias"}

Otro rasgo estructural de la política uruguaya, que mucho tiene que ver, por otra parte, con la centralidad del papel de los partidos, remite a su fuerte proclividad a la permanencia y a la continuidad. Desde las primeras décadas del siglo, el sistema político uruguayo podía asimilarse a la famosa expresión con la que el fallecido historiador francés Fernand Braudel refería al fenómeno de las estructuras resistentes al cambio: "prisiones de larga duración". Ya por entonces en la política uruguaya parecía más fácil "conservar" y "permanecer" que "innovar", y ello se reflejaba muy especialmente en la dinámica del funcio. namiento de los partidos, caracterizada por la continuidad de algunos de sus rasgos más señalados. Como atenuante de lo que puede sonar en algún sentido como determinista, a nuestro "ya por entonces" debería confrontársele con todo lo que pudo haber sido y no fue, con lo que Carlos Real de Azúa prefería llamar "cursos cancelados" o "desarrollos frustados" del sigloxix uruguayo.

Por cierto que la persistencia de las estructuras políticas uruguayas no puede entenderse como una inmutabilidad absoluta. Al contrario, el caso uruguayo bien puede utilizarse como un ejemplo confirmatorio de la idea de David Easton acerca de la persis-

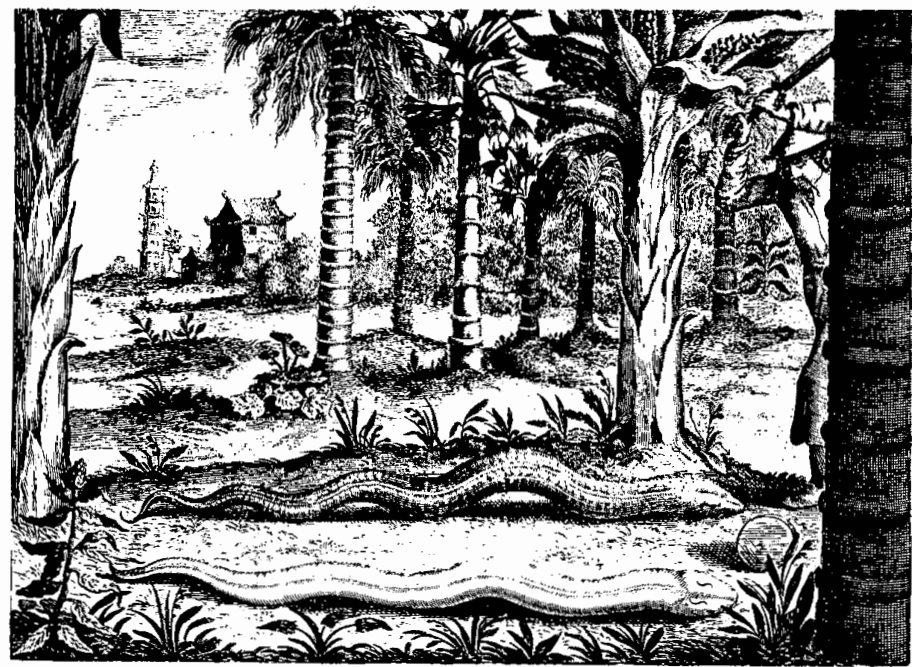

LA PARIIDOCRACIA URUGUAYA 
tencta con cambio y a través del cambio. En esta perspectiva, el registro de la supervivencia continuada en las formas, estructuras y agentes de la vida política uruguaya -en especial de sus partidos- supone, como veremos más adelante, incorporar de inmediato esa noción del cambio compatible con la continuidad. De allí la trascendencia del señalamiento de fenómenos como la capacidad de los partidos uruguayos de adaptarse por autotransformación, la persistencia de su sistema de lealtades y de su iden. tidad histórico-tradicional con actores políticos del pasado, la influencia de su permanente dialéctica entre novedad y tradición. 9

Política de permanencias entonces -tanto "buenas" como "malas"-, en cuya génesis una vez más se refuerza la noción de la centralidad de los partidos en la escena política uruguaya. La homeostasis del conjunto del sistema político tenía allí uno de sus cimientos más arraigados y también su traducción quizás más señalada.

\section{Implicancias del enfoque}

Concebir la historia política uruguaya como "historia de partidos" implica sin duda reinterpretar la significación de procesos y acontecimientos cruciales, más radicalmente aún, implica modificar la ponderación de los hechos conocidos, realzar algunos hasta hoy menospreciados y profundizar el estudio en zonas relativamente desatendidas. Es posible que ello permita, por ejemplo, aproximar el saber académico

\footnotetext{
${ }^{9}$ Cfr. Easton, Esquema, 1979.
}

con la ceremonia y el jutcio popular sobre aspectos de la política partidaria, con obvias repercusiones en los análisis de las confrontaciones y las tareas de la actualidad.

Una historia de la política uruguaya con los partidos como sujetos principales reformularía, entre otros tópicos, el que se vincula al origen de la democracia pluralista y las prácticas de coparticipación en el gobierno. Unas y otras aparecerían entonces, probablemente, como resultado de múltiples avances, retrocesos y acumulaciones, en un principio rudimentarias, cumplidos por los agrupamientos partidarios masivos, con frecuencia de rasgos caudillescos. Los fundamentos de la democracia del país, que ya no se observarían como colocados en pocos años y en virtud de la acción de pocos hombres, se afirmarían en las luchas del siglo XIX y en pautas culturales gradualmente elaboradas. Esa mejor comprensión histórica se proyectaría sobre la evolución actual del sistema partidario y habilitaría una interpretación más ajustada y pronósticos más sagaces acerca del impacto de muchos de los fenómenos más contemporáneos de nuestra vida política.

Asimismo, este énfasis en la acción de los partidos no supone en modo alguno conceptuarlos como los actores únicos o exclusivos de la política uruguaya, ni menoscaba el papel cumplido por otros actores. Antes bien, da cuenta de un fenómeno estructural en el conjunto del sistema político, cuya trascendencia se refuerza precisamente en la atención y en el análisis del papel desempeñado por los otros actores (grupos de presión empre- 
sariales, sindicatos, fuerzas armadas, etc.) en frecuente articulación operativa con los partidos.

LA HIPÓTESIS Y SU HISTORIA. EL LEGADO POLÍTICO DEL SIGLO XIX

\section{Puntos de partida}

Aunque tal vez hundan sus raíces en las tensiones de la patria vieja, es sabido que los "bandos" políticos del Uruguay se definieron, con imprecisión, una vez concluida la primera fase de la crisis independentista (182030) y concluida también la estructu. ración del primer marco constitucional. La configuración moderna del sistema partidario (1910-1934) responde en gran medida a dos singularidades fácilmente apreciables de nuestra historia política: la del legado del siglo XIX $y$ las de nuestro proceso de modernización.

No es posible aludir al legado decimonónico sin partir de una lúcida precisión de Carlos Real de Azúa que no evitaremos transcribir:

Si hay que partir de un hecho-mejor dicho de un cuadro de fenómenos- éste no puede ser otro que la patente, innegable debilidad que en el Uruguay del siglo XIX presentó la constelación típica de poder del continente. La hegemonía económico-social de los sectores empresarios agrocomerciales y su entrelazamiento con la Iglesia y las fuerzas armadas como factores de consenso y respaldo coactivo, respectivamente, no asumi 6 -se decía- la misma consistencia que poseyó en casi todo el resto del área latinoamericana.
Cuando asome el nuevo siglo será tarde para conformar esa constelación, pero quedará abierto el espacio para el impacto de los fenómenos políticos de la modernidad, que se desplegará con comodidad durante las primeras déca. das del siglo $\mathrm{XX}$.

Puede considerarse también parte del legado la consolidación efectiva del tradicic nalismo bipartidista. El mismo implicó, en un proceso de tensión y alimentación recíprocas, la definición de un estilo casi siempre reductible a las respectivas historias partidarias, ordenadas en torno a implicancias socioeconómicas, símbolos y fidelidades genealógicas. Correlato de tales persistencias es el fracaso de los sucesivos intentos de su superación. Aquellos partidos del siglo XIX, tal vez de masa pero no de masas electoras, lograron superar la embestida que desde su interior o el exterior pretendió quebrar el bipartidismo básico. El Fusionismo (1853-1863), el Principismo (1872-1876) y el Constitucionalismo (1881-...) no supieron convocar a aquellas masas y más bien sirvieron de precedente al carácter marginal de los "partidos de ideas" más modernos. Dicho esto sin perjuicio de reconocer que tal marginalidad no supuso en forma alguna un aislamiento: no es magra la lista de sus "aportes" a los partidos tradicionales. Seguramente fueron ellos también "partidos picana", como diría más tarde del suyo, el dirigente socialista Emilio Frugoni.

Es indudable además, una debilidad congénita del Estado patricio de 1830 , incapaz de acotar una población en un marco territorial largamente 
indefinido y extraerle recursos para su mantenimiento. Fue con el militarismo que la presencia del Estado se volvió notoria (consolidó la propiedad privada, comenzó a implantar un sistema educacional de masas, eclipsó al caudillismo, reasumió compromisos financieros internacionales), transformándose en referencia ineludible de poder político. De alguna manera -es este otro legado- la ubicación en el proceso político nacional comenzará a depender desde entonces de la relación de los actores con el aparato del Estado.

\section{Los núcleos de la controversia}

Diversas instancias problemáticas contribuyeron a dar perfil a las distintas opciones partidarias. Así por ejemplo, la enconada lucha por la tierra, mientras persistió, alimentó una dinámica de premios y castigos por el accionar político y un estilo de confrontación predominantemente bélico y rural. Las guerras civiles, al confundir las luchas por la tierra con la lucha de divisas, le dieron a ésta un contenido épico que nutrirá su carácter de "tradicional". Agreguemos que, como es sabido, una cierta hegemonía "blanca" en la campaña significó una acotación ambiental que podría explicar el acento más conservador y la dirección más regionalizada. Es obvio que lo completamente opuesto no pertenece al Partido Colorado, que si se apostó en la ciudadpuerto, tuvo orígenes no menos rurales y tal vez más genuinamente caudillescos que su adversario.

El orden político expresado en la
Carta Magna de 1830 fue también un permanente núcleo de controversia. Aquella primera Constitución puede ser vista, entre múltiples perspectivas, como la negación de un pasado faccional -por no decir partidario- y como la prevención respecto a un futuro tensionado por los partidos políticos. Éstos no estaban previstos en el funcionamiento político que se regulaba y su tumultuaria consistencia fue a su vez la más cabal impugnación a la ilusión patricia de 1830 .

No es menor el problema de la identidad nacional. Configurado el Uruguay con alguna antelación a los uruguayos, las fronteras estatales demoraron en coincidir con las fronte. ras partidarias. Partidos políticos restringidamente nacionales no los hubo hasta el fracaso de la experiencia nacionalista de Bernardo Berro y, más aún, hasta concluida la segunda fundación del Estado durante el ciclo militarista. La irresolución de la "cuestión nacional", junto al reiterado trasiego de ejércitos de ocupación extranjeros y contingentes de inmigrantes, obligó a los partidos -desigualmente permeables- a una estructuración abierta, dispuesta a incorporar gentes y novedades. Así, la "cuestión nacional" -entendida aquí como "cuestión uruguaya"-, más allá de las adscripciones que implicó la Guerra Grande (1839-1851), no fue frecuente tema de pugna entre partidos, y más bien parece no ser exclusivo mérito de ninguno de ellos el logro de tal identidad. La posterior búsqueda de un Artigas "fundador" de la misma, de un Artigas "uruguayo" que no es blanco ni colorado pero al que todos terminaron por 
incorporar, será una confesión de impotencia para asignarse aquel mérito en exclusividad.

Parcialmente vinculado a la "cuestión nacional", adviértase que los partidos políticos -más precisamente sus elites- surgieron sin un contexto de referencias básicas y comunes en lo que se vincula a la política internacional del país. Faltó un cuerpo de premisas aceptadas por todos (al estilo del "principio de no intervención") e incorporadas a la convivencia y a los sistemas de decisión política. Ante un vacío tan prolongado y más allá de las determinaciones ineluctables de la política mundial, los primeros gobiernos del siglo XX tendrán casi todo por hacer también en materia de política internacional.

La ya aludida debilidad del Estado como poder coactivo equiparó por largo tiempo la fuerza del gobierno con la de cualquier grupo de la sociedad civil dispuesto a la rebelión. En consecuencia, hasta la definición de la distancia tecnológica entre el gobierno y los gobernados (1876-1904), los partidos políticos -gobernantes u opositores- vieron en la estrategia de la guerra civil una posibilidad de acceso, de consolidación o desalojo del poder. De allí una conformación un tanto bicéfala de los mismos, con una cara en los grupos armados rurales que disputaban el poder regional, la tierra y el ganado -rasgo éste más acentuado en los blancos-, y con otra en la ciudad-puerto, atenta a la renta aduanera, al menguado presupuesto, a los parlamentos y a la cultura escrita de los círculos.

También fue legado del siglo XIX un estilo de "hacer política" en cada uno de los partidos, que será retomado por ellos hasta nuestros conflictivos días. De alguna manera, los estilos fundamentan la "tradicionalidad" y se construyen a partir de las referencias que encuadran a los actores. Son claves, en ese sentido, las relaciones del partido con el Estado y las clases sociales.

Cuatro décadas de posesión del gobierno y del Estado enlazaron al Partido Colorado al proceso de formación de la burocracia política y del ejército nacional. Tal "privilegio" lo aventajó respecto a los blancos, en la medida que significó poseer instrumentos de control y dominación sociopolítica. Las relaciones con la sociedad, en cambio, no permiten detectar tal predominio de uno de los partidos. En tal sentido, blancos y colorados podían pugnar en condiciones relativamente similares; ambos podían ocupar un espacio vertical en la sociedad uruguaya de los comienzos del siglo XX.

\section{Algunas cuentas pendientes}

Más allá de tales y tantos "haberes", quedaban aún cuentas pendientes de solución. La breve historia del Uruguay permite descubrir la lentitud de las respuestas de lo político partidario, no sólo ante coyunturas adversas sino ante márgenes más amplios de maniobra. La respuesta lenta dejó vacíos que no es díficil advertir.

Luego de la Guerra Grande, la modernización productiva era imperiosa y los partidos respondieron a ella tarde y mal. La guerra civil y la querella 


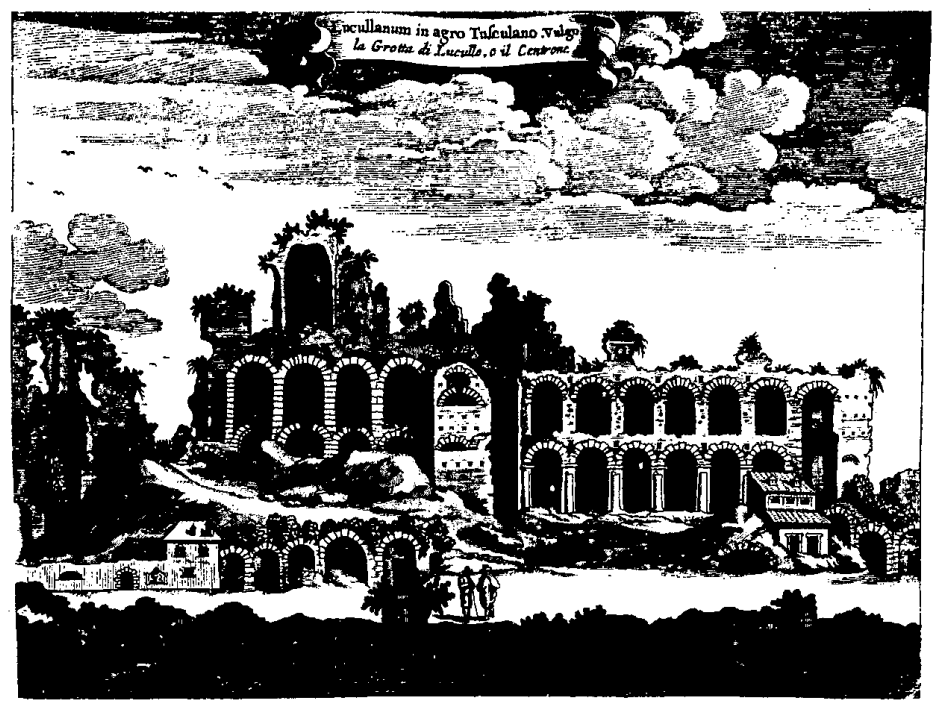

palaciega resultaron la única respuesta de hecho, funcional a las colectividades políticas pero no a la oligarquía agrocomercial, que no encontró una vertiente partidaria que alojara su proyecto, confiado finalmente al ejército. Debe acotarse sin embargo que si éste comenzaba a cobrar un perfil corporativo y "moderno", lejos estaba de perder sus vinculaciones con los partidos, en este caso y cada vez más, con el Partido Colorado.

En la última década del siglo, aunque la ciisis del 90 promoviera unas pocas conciencias críticas -anticipación intelectual del reformismo-, los partidos como tales no innovaron en sus formas de encarar la fase expansiva del país. La guerra civil y la regionalización de las elites, fueron no sólo lastres y contradicciones de la dinámica anterior, sino una nueva y lenta respuesta a las exigencias finiseculares.

Es que, extremando el análisis, partidos políticos en el sentido moderno del término no existen sino a partir de las primeras décadas del siglo XX. La política no significaba notoriamente lo mismo para las elites dirigentes que para las masas. Más que sobre el "destino del país" se discutía sobre el "poder", y el discurso político parecía entonces impermeable a la "cuestión social". Otra lenta respuesta, otro vacío que sería colmado en el siglo $\mathrm{xx}$.

La sociabilidad política nacional no exigía de los partidos una estructuración moderna, determinada por una apuesta a los periódicos exámenes electorales. En medio de la indiferencia o del abstencionismo, no fue necesario generar instancias de recluta- 
miento más o menos permanentes de las masas electoras. Bastaba, en todo caso, con arbitrar instrucciones a jefes políticos o caudillos de pago, los que, exigentes de contraprestación, hacian por cierto difícil la tarea del jefe nacional.

La formación de los "bandos" políticos resultó además contemporánea a la lucha por la hegemonía entre las clases dominantes, que trenzó al patriciado arruinado en las guerras civiles, de las que fue gestor y partícipe, con la estirpe de nuevos ricos ligados al aluvión inmigratorio. La derrota del primero determinó una cierta ajenidad para con el país real, al tiempo que un proceso de profesionalización de la función política. Para los segundos, una ajenidad a la inversa, la que los llevaría, a la postre, al desprecio de la "clase política" o a su definición como grupo de presión, aún no totalmente moderno. Entre tanto quedaba alli otra cuenta pendiente: la de la representación de la oligarquía agraria y comercial $-e$ industria incipiente- en el conjunto de los partidos políticos. Cuando fue necesario responder al desafio del contexto, la oligarquía presionó por fuera de los partidos políticos. Se vio "representada" por el ejército, que aunque de otro origen social, garantizaba, en el corto plazo, una relativa autonomía de la vida partidaria de estilo doctoral y principista. La instancia del militarismo, percance para unos y chance para otros, demostró que los partidos políticos no eran percibidos como instituciones que hicieran viable el proceso de modernización de la estructura productiva del país.

\section{Una modernización peculiar}

Si bien la modernización del Uruguay fue similar, en sus resultados, a la de las demás áreas de la América periférica, su proceso mantuvo notables singularidades. La más evidente a nuestro juicio es la que nos muestra a una sociedad que transcurre incorporando nuevos sectores, volviéndose cada vez más compleja pero sin la acumulación -mejor aún, sin la síntesisque el proceso modernizador supone. Los sectores sociales beneficiados se "agregan", pero no sintetizan lo precedente ni definen las etapas posteriores; sólo un Estado de creciente pujanza es capaz de encuadrar las fuerzas que se proyectan desarticuladas y faltas de un proyecto nacional relativamente común y persistente que las convoque. La modernización, en síntesis, más que a través de etapas acumulativas, transcurrió por "capas" superpuestas, integrando diferente y paulatinamente a distintos grupos sociales que, aunque escasamente dependientes entre sí, coincidirían en el Estado como referencia obligada y garantía.

La primera fase durante el ciclo militarista demandó la creación del Estado moderno, con las consiguientes novedades que ello suponía: se obtuvo el reconocimiento del país como "entidad soberana" en el marco de las relaciones internacionales; se institucionalizó la autoridad; se logró el monopolio de la coerción; se concretó la capacidad de extraer recursos asiduamente y se dio comienzo al despliegue simbólico que reforzó el sentimiento de pertenencia y solidaridad y permitió el control ideológico de la 
sociedad. Tal el Estado que requerían la modernización y la clase alta rural y comercial a ella ligada. Así se integró la estancia-empresa al proceso económico y así fueron marginados y reprimidos los numerosos y pobres sectores populares rurales.

Pero "gringos" y paisanos pobres y desplazados tendrán "su hora" durante la segunda fase. Se integrarán parcialmente al proceso modernizador del reformismo batllista como una "capa" más y por la mediación estatal, a través de la expansión de las funciones primarias y secundarias (burocracia militar y civil) y a través del proteccionismo industrial. La secuencia muestra claramente que las capas integradas durante la modernización batllista no tuvieron ligazón con el proceso productivo desatado por la estancia-empresa durante la fase latorrista (1876-1880). Sólo el Estado -y de alli su primacía sobre la sociedadpudo atemperar una confrontación que finalmente se desató en contra del batllismo y marcó los límites de la modernización.

Claro que el batllismo aspiró, y con variado éxito, a concretar avances que aliviarán algunas de las más molestas polaridades decimonónicas: la del campo frente a la ciudad, la de nacionales y extranjeros, la de la lucha armada frente a la puja electoral. No menos integrador era el sueño del país-granja agropecuaria, que retendría a los desplazados por la tecnología y el subempleo de la tierra, o la política distributivista basada en la apropiación de los excedentes (nacionalización, estatización, política impositiva). Sometida a la prueba elec- toral y desafiada por el sufragio universal to que también implicaba un empuje modernizador-, la propuesta reformista resultó bloqueada y malherida. De allí en más, requerirá fatalmente del compromiso con los sectores conservadores, con el fin de mantener la hegemonía de "los partidos colorados".

Importa reparar en el correlato político del proceso modernizador, en la medida en que permite medir la funcionalidad de los agentes políticos frente a las transformaciones sociales. La modernización latorrista por ejemplo, prescindió de los partidos políticos, sobre todo de sus alas doctorales, pero no los aniquiló. Más aún, cuando se restauró la democracia oligárquica, se reanimaron los viejos actores que parecieron despertar de un sueño que poco tenía de pesadilla. Los partidos políticos, en suma, no "hicieron" la primera modernización, pero tampoco murieron a su paso.

Distinta es, en parte, la historia cuando observamos la fase batllista. Aquí las transformaciones sociocconó micas impactaron a los partidos políticos, catalizaron su conformación en un sistema y los forzaron a sucesivos reajustes que, sin embargo, no quebraron algunas de las más tenaces continuidades del siglo anterior. La tradicionalidad y la permanencia parecen haber sido un vehículo idóneo (¿tal vez el único?) para el cambio del sistema partidario del Uruguay.

Los partidos resistieron la embestida del cambio social y, más aún, la interpretaron cabalmente procesando reajustes que aseguraron en definitiva su permanencia. La electoralización y 
"civilización" de la lucha política en grados crecientes de complejidad institucionalizada y la renovación de la temática en pugna no fueron más -ni menos- que instancias en las que el sistema de partidos políticos dio cuenta de los cambios, haciéndolos posibles aunque nunca profundos. El Estado mismo, más consistente que la sociedad que decía representar, con su despliegue providente y asistencial, colmó vacíos, ocul tó abstenciones y en última instancia aseguró a los partidos.

Podría admitirse que la peculiaridad de la modernización uruguaya reposaba, en parte, en el legado del siglo xx esbozado ya anteriormente. Pero este legado no era menos peculiar: aunque con una tradición cristalizada y con largos precedentes de gobierno en uno de los partidos, dejaba un amplio margen para las innovaciones y las consolidaciones. Al despuntar el siglo, casi todo parecía posible, aun conservando lo esencial. No casualmente José Batlle y Ordóñez llegó a recomendar con insistencia hacia el 900 el "aprovechar estos tiempos de formación".

\section{El NACIMIENTO DEL SISTEMA DE PARTIDOS}

El lapso formativo: 1910-1934

En el marco de ese proceso de modernización general del país, el sistema político uruguayo vivió también en las primeras décadas del presente siglo no sólo fases finales de su transformación sino incluso la configuración originaria de muchas de sus estructuras (su sistema de partidos entre ellas), que

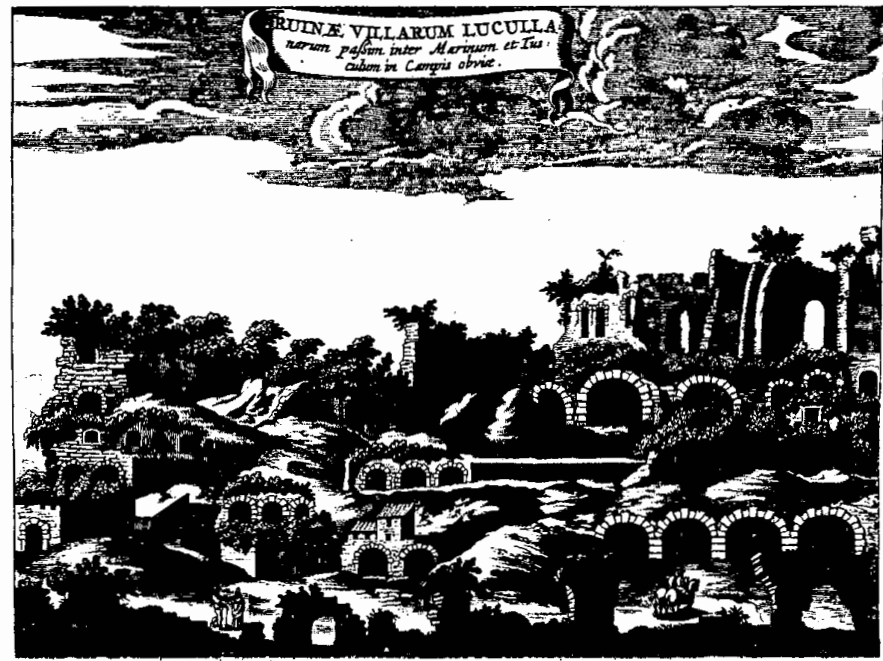

LA PARIDOOCRACIA URUGUAYA 
habrían de permanecer en algunos ca. sos sin cambios fundamentales hasta nuestros días. Los científicos políticos contemporáneos han puesto de manifiesto en los últimos tiempos la trascendencia que reviste el análisis del periodo de formación de los sistemas partidarios, señalando que el desarrollo ulterior de éstos, por lo general, depende en buena parte de las características que asume su con. formación originaria. Con esto han querido señalar que un sistema de partidos es en extremo sensible a los condicionamientos externos, fundamentalmente en su etapa de formación, pues una vez constituido, por lo general, mantiene sus caracteristicas esenciales o bien se transforma de modo muy lento, a menos que sea destruido o modificado sustancialmente por conmociones políticas profundas. Sin duda la dinámica del sistema de partidos políticos uruguayos, a lo largo de todo el siglo $\mathrm{xx}$, ha ofrecido en forma global ese signo de permanencia referido.

Pensamos que el periodo comprendido entre 1910 y 1934 sirve como marco cronológico idóneo para lo que hemos dado en llamar la etapa formativa de nuestro sistema partidario. Quizás un registro aun sumario de algunos de los acontecimientos y procesos políticos que se desarrollaron en esos años en el país, permita orientar una explicación acerca del criterio de periodificación utilizado: en ese periodo se consolida la modernización de los "partidos tradicionales"; aparecen los llamados "partidos de ideas" modernos; se renueva la temática y los instrumentos del debate político; se electoraliza la oposición nacionalista que abandona el recurso de la gue. rra civil; se produce el ingreso de las masas a la política electoral a través de la aplicación del sufragio universal por primera vez en el país; la vida democrática adquiere mayor consistencia y credibilidad en el seno de la ciudadanía; las corrientes ideológicas universales aumentan su influencia en el país y comienzan a constituirse en referencias más frecuentes en el de. bate público; la sociedad entera se politiza en el sentido moderno, tanto a nivel individual como de sus componentes colectivos (sindicatos, grupos de presión patronales, etc.); se inauguran formas estrechas de relacionamiento entre los partidos y otros agentes políticos modernos; se establece en forma gradual y progresiva el sistema electoral que sería el tradicional en el Uruguay del siglo $x x$, etcétera.

Incluso los dos años que hemos postulado como limitantes para el periodo en cuestión, refieren a eventos y situaciones de crucial importancia en el proceso político del país. En 1910 se produce el fracaso de la última intentona revolucionaria nacionalista de acuerdo al viejo estilo del siglo $\mathrm{xIX}$; el Partido Nacional se abstiene en las elecciones, pero en su seno comienza a predonimar la fracción "conservadora" o "civilista"; Batlle y Orcóñez es proclamado candidato a la presidencia y su Partido Colorado triunfa en forma abrumadora en los comicios, a los que se presentan también por primera vez el Partido Socialista (en coalición con el Partido Liberal, obteniendo una banca para su conductor, el Dr. Emilio Frugoni) y la Unión 
Cívica. En 1934, a su vez, Gabriel Terra resulta electo presidente por la Asamblea General constituyente, consolidándose así el régimen iniciado el 31 de marzo del año anterior; se sanciona y plebiscita una nueva constitución teniendo grandes cambios institucionales respecto de la anterior; se realizan elecciones de legisladores $\mathrm{e}$ intendentes con la abstención del batllismo y del nacionalismo independiente; se sanciona la primera de las leyes que junto a ciertas reformas constitucionales conformaría posteriormente el paquete de disposiciones electorales comúnmente conocido como "ley de lemas".

Es dentro de ese marco cronológico que los partidos políticos uruguayos comienzan a actuar en tanto componentes de un sistema, coexistiendo e interactuando entre sí en forma más o menos continua y en un mismo nivel de actividad, comunicándose estrechamente con los actores políticos no partidarios de la sociedad, e incluso brindando legitimidad y mayor cohesión al conjunto del ámbito de relaciones políticas. Con anterioridad a 1910, pese a la existencia de indicios modernizantes en la acción de los partidos, éstos no actúan de acuerdo a las características anotadas y en consecuencia no puede señalarse a nuestro juicio que hayan tendido a constituirse en un sistema unitario.

\section{Registro de cambios}

Pero si bien su configuración como componentes (plenos o parciales) de un mismo sistema constituyó tal vez el evento más relevante de la moderni- zación de los partidos, no por ello la consideración de ese fenómeno agota el registro de sus grandes y múltiples transformaciones en esta etapa. Támbién como unidades, los partidos políticos uruguayos experimentaron en aquella época una fuerte renovación de sus características más salientes.

Comencemos por señalar en un rápido sumario no exhaustivo algunos de los cambios más notables ocurridos en su acción durante las primeras décadas del siglo: surgieron nuevos partidos identificados directamente con los "asuntos" de la modernidad; los viejos partidos preexisten. tes se abrieron a nuevos sectores $y$ temáticas; se comienzan a promover prácticas políticas inéditas o por lo menos poco frecuentes en el pasado (realización de actos callejeros multitudinarios, utilización de medios de propaganda novedosos y masivos, prolongación-lograda sólo a veces en forma plena, pero intentada reiteradamentede la vigencia de la vida partidaria más allá de los periodos electorales, etc.); se extendió la reorganización estructural de los partidos bajo moldes diferentes, lo que llevó a una modificación profunda, en algunos casos de los estilos de conducción y del funcionamiento de los respectivos aparatos partidarios; se produjo una adaptación rápida y efectiva de todos los partidos a las exigentes de la electoralización casi explosiva de la vida política del país (como hemos visto entre 1905 y 1931 el número de sufragios en los comicios nacionales se multiplicó casi por siete); la ampliación del Estado condujo a su vez a una profun- 
dización de las prácticas y relaciones clientelísticas (en las que, además del Partido Colorado como partido del Estado, poco a poco comenzaron a involucrarse también sectores del nacionalismo); se acrecentaron las demandas -no siempre satisfechas, es ciertode sectores de la sociedad por formulaciones programáticas más precisas y orgánicas de parte de los partidos, lo que coadyuvó en algunos casos a una receptividad mayor frente al curso de las grandes corrientes ideológicas mundiales; se amplió y diversificó el espectro de relacionamiento de los partidos con otros actores políticos no partidarios (sindicatos, grupos de presión empresariales, compañías extrajeras multinacionales, grupos dentro de las fuerzas armadas, etc.); entre otros muchos fenómenos y procesos no menos importantes.

Sin embargo, pese a ese cúmulo impresionante de cambios cuya enumeración podría continuarse, la modernización de los partidos no escapó tampoco a esa tensión entre renovación-permanencia tan propia y característica de todo proceso de transformaciones de índole colectiva. Esa contradicción pudo observarse de modo particular en el batllismo, que como "partido de la modernización" ejerció por entonces un innegable efecto dialéctico sobre los otros. Barrán y Nahum han destacado gráficamente esa característica, señalando que el nacimiento y la acción de Batlle y sus hombres dentro del Partido Colorado referían de inmediato a la imagen del "vino nuevo en odre viejo".

La persistencia del arraigo de la doble tradicionalidad blanquicolorada y de su correlato más evidente, el "bipartidismo" electoral, oficiaron en este sentido de auténtico telón de fondo para el origen de múltiples inercias en la vida de los partidos uruguayos, lo que -como veremosmarcó su modernización con tinte conservador.

\section{Registro de permanencias}

En todo este panorama político-partidario que se iba perfilando al avanzar el proceso de modernización de los partidos, comenzaban a hacerse visibles no pocos rasgos conservadores. Sin duda que esto es algo que el investigador actual puede registrar con la perspectiva que le aportan los años transcurridos, pero que los uruguayos de entonces difícilmente podían distinguir $O$, a lo sumo, veían sólo a medias. En efecto, con el telón de fondo algo engañoso de los variados cambios operados en la acción de los partidos, emergían o se consolidaban dinámicas y fenómenos políticos con un fuerte poder de inercia de cara al futuro, destinados los más de ellos a producir un cierto congelamiento en los marcos de la política uruguaya.

Señalaremos algunas de esas características de nuestro sistema de partidos que habrían de constituirse con el tiempo en auténticas permanencias de nuestra vida política:

Continuidad y fortalecimiento del tradicionalismo político. Desafiados por el duro examen que significaba la implantación del sufragio universal, los partidos tradicionales recibieron sin embargo en esos años una plena confirmación electoral, casi de- 


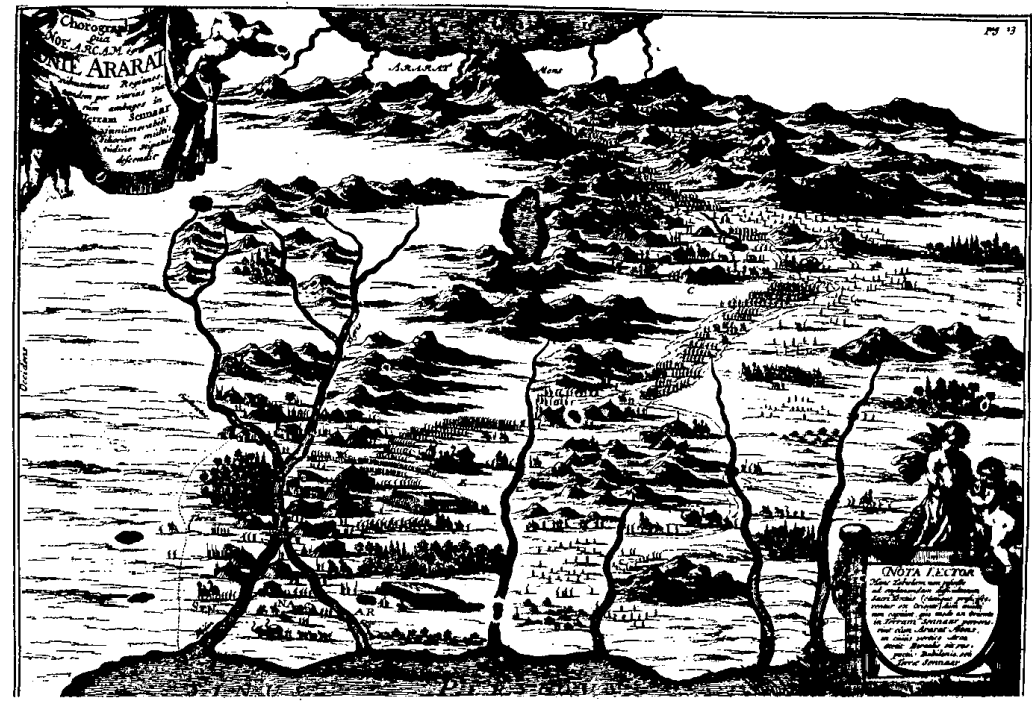

mostrando así que su arraigo era en verdad popular, incluso en el seno de un electorado en buena parte nuevo, aluvional y en apariencia no tradicionalizado a priori (inmigrantes, trabajadores, las nuevas generaciones novecentistas, etcétera.)

Bipartidismo electoral y multipartidismo cotidiano. El bipartidismo tradicional funcionaba como tal únicamente en las instancias electorales, encubriendo luego la plena vigencia -en la dinámica política más corriente- de un sistema de partidos múltiples.

Policlasismo marcado en los partidos. Los partidos políticos -fundamentalmente los llamados tradicionales, pero no sólo ellos- proyectaron un corte más bien vertical de la sociedad civil, trasladando a su interior los conflictos sociales y promoviendo a par- tir de allí proyectos sociales -cuando los hubo- diseñados por los sectores predominantes en el pacto social implítico dentro de la vida partidaria.

Sistema electoral funcional a la permanencia de la estructura partidaria configurada. Normas electorales como la del doble voto simultáneo, las diversas formas de acumulación de votos, la propiedad de los lemas por las mayorías, etc., consagrados inicialmente en este periodo, posibilitaron la compleja traducción del "multipartidismo" real en ese "bipartidismo" electoral, que terminó de atarse en forma definitiva a la famosa "ley de lemas".

Congelamiento relativo de la constelación partidaria, por ejemplo en las dificultades de arraigo de las "terceras fuerzas", en los duros es:ollos encontrados por los movimientus di- 
sidentes con preocupaciones ideológicas dentro de los lemas tradicionales, en los obstáculos casi insalvables para la concreción de coaliciones electorales o políticas que no se correspondieran con los cánones de la tradición.

Liderazgos políticos fuertemente integrados a la dinánica general del sistema partidario. A diferencia de lo ocurrido en otros países latinoamericanos durante esta misma etapa de modernización política y de la configuración originaria del sistema partidario moderno, en el Uruguay no se produjo la irrupción de liderazgos fuertemente mayoritarios y con características por lo general disímiles y aun contrapuestas a la tradición política del siglo XIX. En fecto, no se dio aquí un liderazgo totalizador $y$ absorbente, sino que por el contrario se procesó una disputa incluso dialéctica de liderazgos: la figura de Batlle y Ordóñez debió enfrentarse a nivel nacional con la jefatura nacionalista de Luis Alberto de Herrera, y aun dentro del Partido Colorado debió consentir la división de las adhesiones con otros líderes como Manini Ríos o Viera. Asimismo, ninguno de estos liderazgos de mayor arraigo se proyectó como ajeno a la tradición, sino que incluso lucharon unos contra otros muchas veces por presentarse como los máximos exponentes de la continuidad histórica de cada una de las divisas, cifrando allí buena parte del éxito de su poder de convocatoria electoral. Por su parte, por sus propias características, los "partidos de ideas" no generaron liderazgos de tipo personalista, prefiriendo en cambio conducciones de signo colegiado. (En ciertos aspectos, el pa- pel de Frugoni dentro del Partido Socialista en esta etapa podría señalarse como una excepción a esta generalización, aunque su estilo político y su poder de convocatoria resultaron claramente disímiles respecto de las formas asumidas por los liderazgos de los partidos tradicionales.) En todos estos casos los diversos liderazgos partidarios evidenciaron una fuerte depedencia respecto de la dinámica de funcionamiento general del sistema partidario en formación, no pudiendo trascenderlo en ningún momento.

Vinculación estrecha con el sistema de partidos y el Estado. Las diversas formas de coparticipación a nivel de la administración pública y de reparto y "cuotificación" del poder estatal entre ambos partidos tradicionales, no sólo ambientaron el clientelismo con fines electoralistas, sino también con. tribuyeron a reforzar la complementariedad y admisión recíproca de esos partidos dentro del sistema. La ajenidad y aun la denuncia que los "partidos de ideas" realizaron respecto de esas prácticas, no llegaron a cuestionar mayormente su prolongación en el tiempo. Más aún, la compenetración entre ambos partidos tradicionales y el Estado constituyó un nuevo factor de estabilidad para la hegemonía de aquéllos dentro del sistema partidario.

Firme relacionamiento $e$ intercomunicación entre los partidos de derecha y los grupos de presión empresariales, lo que se verificó en un sentido recíproco y bilateral y otorgó una fuerte y perdurable ventaja a los intereses conservadores en la correlación de fuerzas con los sectores populares.

Inexistencia de un sistema de re- 
lación directa partido gobernantesindicatos, aspecto distintivo del batllismo y del movimiento sindical uruguayo en el contexto de América Latina, sobre el que ha insistido en sus trabajos recientes el historiador norteamericano David Collier.

Podrían señalarse otras muchas inercias (la estabilidad relativa de las dirigencias, la profundización de la tendencia al acuerdismo entre los partidos tradicionales, la dialéctica pendular de esos mismos partidos en relación a su ubicación en el espectro ideológico, el cumplimiento relativamente exitoso por ellos de funciones no estrictamente políticas, entre otras), generadas o consolidadas en este proceso de modernización de los partidos uruguayos, pero el carácter de esta nota no lo permite ni aconseja.

\section{UNA REPUBLICA CONSERVADORA}

A veces la captación de un momento crucial contribuye a desnudar más claramente la estructura que se busca resaltar. En este caso, la coyuntura crítica del golpe de Estado de 1933 pone a prueba la hipótesis partidocéntrica de la política uruguaya, mucho más ostensible, creemos, si observamos a nuestros partidos en el juego de sus relaciones con el Estado y la sociedad.

La crisis social y política que rodeó al golpe de Estado de 1933 en Uruguay, pese a proyectar ciertos tonos de virulencia, no provocó cambios sustantivos sino tan sólo algunos ajustes de relevancia dispar, dentro de un cuadro general de ratificación del "mapa" ya tradicional de esas relaciones en el país. Hacia 1930 la sociedad uruguaya, tal vez por primera vez en su historia, proyectaba el perfil -más o menos borroso, no congelado ni mucho menosde una estructura básica, en buena parte estabilizada y definida también de cara hacia el porvenir. Contribuian a ello el fin del impulso inmigratorio, la configuración (ya muy avanzada por entonces) del sistema político moderno en el país, los avances en el plano más global del proceso de modernización. El impacto de la crisis y la conmoción derivada del golpe de Estado no modificaron -e incluso ratificaron-algunos rasgos estructurales ya por entonces muy típicamente "uruguayos":

a) la beterogeneidad estructural de la sociedad, reflejada en la complejidad de los universos clasistas y del cuadro general de estratificación, lo que se traducía en una notoria dispersión del humus social;

b) La preminencia del Estado y los partidos sobre una sociedad civil débil, sin impulsos endógenos demasiado vigorosos, expresión también de una economía capitalista insuficientemente desarrollada y articulada;

c) baja extensión de las formas de incorporación asalartada al proceso económico, en cuyo marco se destacaba el contraste entre el bajo porcentaje de obreros industriales y uno relativamente alto de "sectores de asalariados improductivos" (base de despegue de esas "insondables" y omnipresentes "clases medias" uruguayas);

d) consistencia de la oposición urbano-rural en el contexto de una resistente primacia (cuestionada pero 


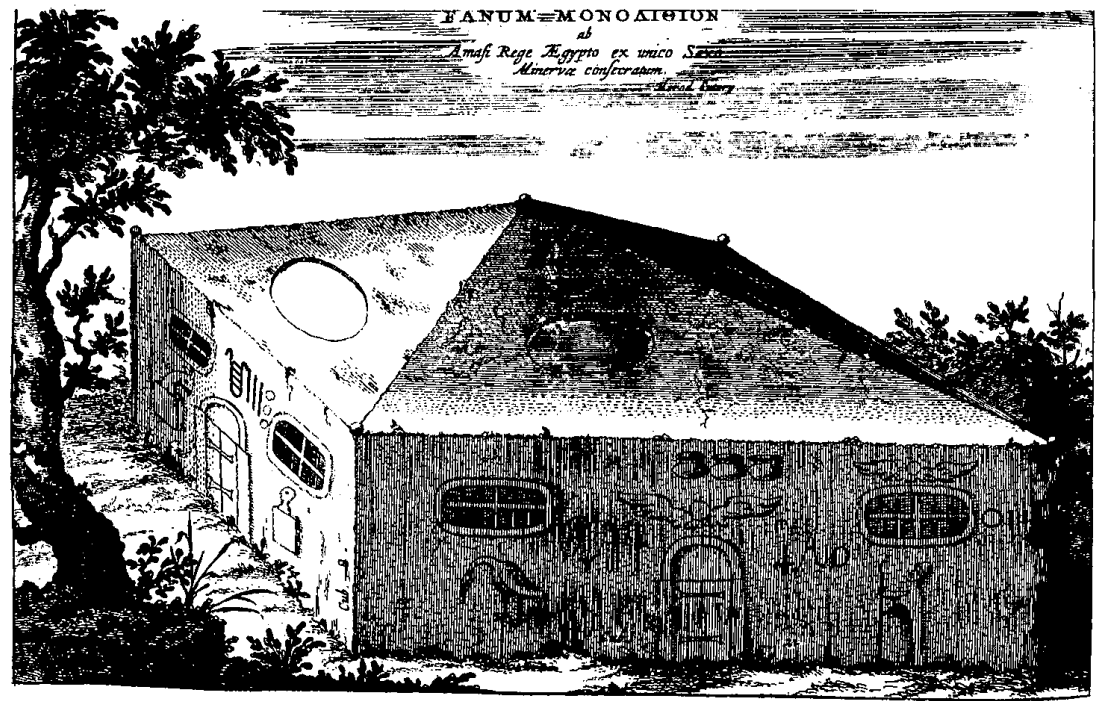

no doblegada) de la capital sobre "el campo", terreno este último del poder incontrastable de los ganaderos y de la fragilidad endémica de los sectores populares rurales;

e) debilidad begemónica tan visible como extendida, expresada tanto por la amplitud de las zonas de desarrollo del Estado como por la ineptitud o imposibilidad de las distintas clases de constelar en su torno un bloque begemónico persistente.

A partir de este marco estructural de tipo general, y enfatizando sobre la pertinencia de un análisis atento de las articulaciones dialécticas entre lo so. cial y lo político, ¿qué reflejos o efectos persistentes podían registrarse entonces en el terreno de los actores sociales y políticos? Enumeremos algunos de los más relevantes: a) persistencia de la centralidad de los partidos como actores dominantes (aunque obvio es decirlo no exclu. sivos) de la política uruguaya (con sus múltiples implicancias en la esfera de la primacía de la legitimidad electoral, la progresiva captura de lo social organizado por lo partidario, etcétera.) ${ }^{10}$

b) presencia también dominante del Estado, incluso actuando a veces como un actor político más (aunque sin desprenderse casi nunca de una fuerte referencia partidaria), ${ }^{11} \mathrm{de}$ sempeñando con frecuencia el papel 37.61

10 Cfr. Caetano, "Partidocracia", 1987, pp.

11 Ibid. En una perspectiva similar en el destaque de aquel "Estado de partidos", véanse Lanzaro, Sindicatos, 1986; Grossi, Partidos, s.f., entre otros. 
de un "centro regulador" casi insustituible, con cierta "consistencia propia" y márgenes de acción relativamente autónoma (io relativamente de. pendiente?);

c) tendencia a la asimetría en la correlación de fuerzas en el marco de un cuadro de polarización relativa (obsérvese el cotejo de factores como cohesión, unidad de conducción, recursos, operatividad política, etc. entre el "bloque conservador-golpista" y el "espacio de fuerzas no golpistas");

d) claro predominio de una matriz de convocatoria ciudadana sobre la alternativa de una posible matriz corporativista, en el contexto de una cultura política que privilegiaba el papel ciudadano (partidario, electoral, etc.) sobre el papel de sujetos del proceso económico; ${ }^{12}$

e) existencia de importantes vacios organizativos en el medio rural y de un divorcio urbano-rural en el campo de la mayoría de las organizaciones populares, lo que facilitaba el éxito de convocatorias no clasistas del tipo de la ruralista y bloqueaba la acumulación de fuerzas en la perspectiva del cambio social;

f) cuadro general aparentemente más favorable a las permanencias que a las transformaciones, sobre la base de un marco de relaciones partidosEstado-sociedad de sólido arraigo entre los uruguayos.

Por cierto que la articulación entre aquella estructura social básica y la esfera de los actores sociales y políticos, entre "lo social" y "lo político"

12 Sobre el tema de las relaciones corporativas en el Uruguay, cfr. Lanzaro, Sindicatos, 1986. en suma, ${ }^{13}$ se presentaba como compleja y dinámica, para nada estática, aun en el marco de esa proclividad a las permanencias que limitaba el espacio de los cambios traumáticos, en una y otra dirección. Esa "república conservadora" no era la simple traducción política de una "estructura conservadora". Tampoco era la consecuencia de una "conspiración" política que habría neutralizado los impulsos vigorosos de una sociedad proyectada al cambio. Como hemos intentado demostrar, se trataba más bien de la resultante de esa articulación compleja y plural entre lo social y lo político, de la dialéctica de sus impulsos y bloqueos, de sus acumulaciones y desacumulaciones. Era también expresión del ya arraigado carácter partidocéntrico del sistema político.

Empero, si por cierto en el Uruguay de 1930 podía decirse (y el mismo régimen terrista así lo corroboraria) que era más fácil conservar que inno-

13 El complejo mundo de la política nunca es -mucho menos en el caso de una política tan refinada como la uruguaya- una simple traducción o epifenomeno de la estructura social. Las identidades sociales dificilmente pueden ser concebidas como elementos fijos o "da. dos", sino que ellas son también el producto de una construcción, en la que ingresa lo propiamente político -definido en términos no excluyentes ni totalizantes- como un espacio de la constitución de identidades. También se ha dicho que a nuestro juicio la política nunca es un "clavel del aire" y que su "autonomía" es siempre relativa; en suma, que la estructura social también "juega" políticamente hablando, y que no existe programa político que pueda ser viabilizado sin un sustento "humus social" (en una acepción amplia del concepto). Tómese esa referencia genérica como marco de muchas de las reflexiones que siguen. 
var, tampoco había nada cristalizado o congelado para el porvenir.

La crisis institucional vino entonces a confirmar de modo indirecto el partidocentrismo uruguayo. A pesar de la trama de realineamiento que en lo previo conmovió al sistema de partidos y del protagonismo decisivo de otros actores en la coyuntura (en especial, de los grupos de presión empresaria. les), el centro de la escena política lo siguieron ocupando los partidos. No hubo aquí espacio para la emergencia efectiva de una "constelación antipartidista", ${ }^{14}$ del tipo de las que se construyeron por entonces en la mayoría de los países de América Latina (por ejemplo en la Argentina). No existió la posibilidad real de que una alternativa extrapartidaria condujera el proceso golpista y se hiciera cargo de las responsabilidades gubernamentales luego de la quiebra institucional. Ni lo uno ni lo otro podía hacerse entonces desde fuera de los partidos. Obsérvese con atención el papel jugado en esa coyuntura por los militares o por las gremiales empresariales y se tendrá un elemento confirmatorio de lo señalado. Incluso que la "ruptura" debiese recubrirse constitucio-

14 Cfr. Cavarozzi, Crisis, 1981. Dice Cavarozzi: "Los actores que desencadenaron la crisis final de los regímenes oligárquicos fueron constelaciones de agentes políticos y sociales [...] (entre cuyos rasgos dominantes figura) su antipartidismo, es decir su rechazo de las puaticticas parlamentaristas y de los políticos profesionales y la postulación de la necesidad de reemplazar la 'política del comite' [...] por una combinación de instituciones y prácticas tecnócratas y semicorporativas que no excluían, en principio, la posibilidad de una movilización de las masas populares controlada desde arriban. nalmente -el debate en torno a diversos modelos de institucionalidad pareció dominar el ámbito político uruguayo antes y después del golpe, lo que por cierto era un gran espejismoindicaba también hasta qué punto los partidos, la matriz de convocatoria ciudadana y los principios generales de la democracia liberal se habían internalizado en el corazón de aquella sociedad. Aun la implantación dictatorial parecía comprobarlo.

Este rápido repaso del itinerario de nuestros partidos durante su modernización nos habilita a un par de reflexiones finales que apuntan a identificar al Uruguay como una república conservadora. República en tanto tarea histórica de partidos y de ciudadanos a través de los cuales se canaliza la mayor parte de la acción política del país; república en tanto siempre fue difícil despolitizar cualquier expresión de la vida pública en el Uruguay. Al contrario de lo ocurrido en la Argentina anterior $y$ posterior a 1930, donde las corporaciones y grupos sociales tuvieron mayor incidencia que los partidos políticos -expresando tal vez una sociedad civil más vigorosa-, la historia política del Uruguay puede ser asimilada, en buena medida, a la historia de sus partidos, a tal punto que no parecen viables empresas colectivas sin su concurso y menos aún con su oposición. Cuando el país salía de la última dictadura, las organizaciones de la sociedad civil parecieron cobrar una fuerza e iniciativa propias que el transcurso del tiempo fue en parte desdibujando. Hoy no parece fácil encontrar actividades sociales, culturales 


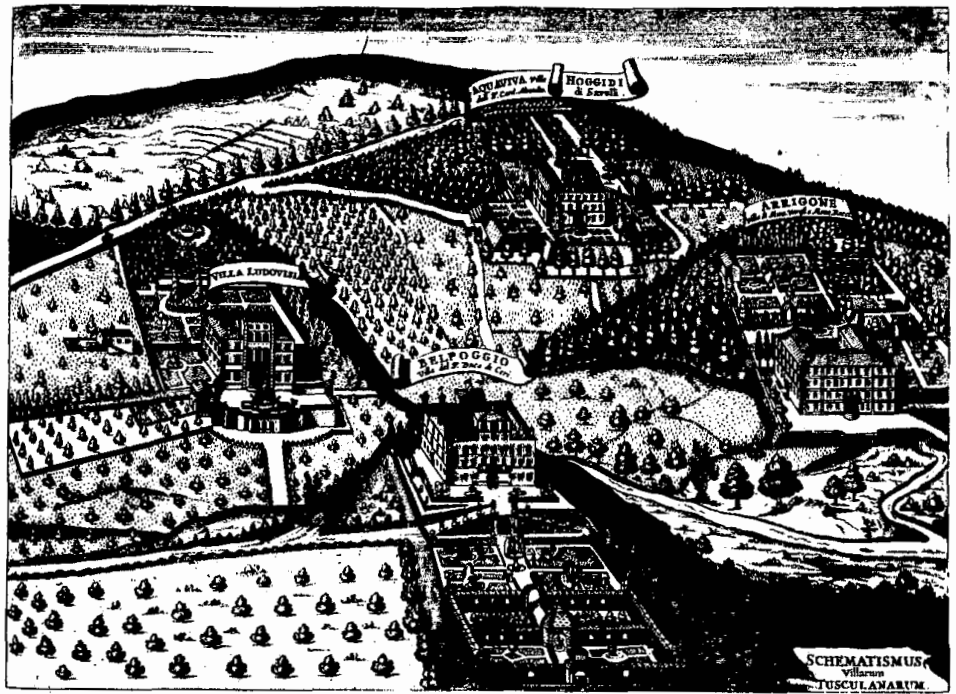

y políticas que escapen de la captura de lo partidario. ¿'Tendrán algún costo tales primacías? Hoy la república recuerda mucho más y mejor aquel "impulso" que su "freno", y tiene nostalgia de su democracia política sin advertir, otra vez ingenuamente, la gravedad de su bloqueo social.

Pero también -la otra cara de la moneda- una república conservadora, hija de aquella "democracia triunfante", que sin embargo nacía con el "estigma" del freno al cambio social. Una "Suiza americana" que detenía su transformación en el momento culminante. Un reformismo que llegó hasta el jacobinismo pero que desde su "cuna de oro" desconfió ante la perspectiva de la movilización popular. Una república, en fin, que supo ser audaz en sus proyectos y moderada en demasía a la hora de su consumación, y que desde su "bovina euforia" prefirió conservar lo que tenía y evitar lo que podía. ${ }^{15}$

\section{Bibl.IOgRafía}

-Barrán, José Pedro, El apogeo y crisis del Uniguay pastoral y caudillesco (183)1875), Ediciones de la Banda Oriental, Montevideo, 1975 (Historia Uruguaya IV). y Benjamín Nahum, Batlle, los estancieros y el imperio británico, EBO, Montevideo, 1986.

-Caetano, Gerardo, Rilla, y Pérez, "La partidocracia uruguaya. Historia y teoría

15 La denominación de república conservadora responde a un doble hurto sugerido por la lectura de Gallo, República, 1972 y de algunos capítulos del t. vi de Barrán, Batl/e, 1986. 
de la centralidad de los partidos políticos", en Cuadernos del CLAEH, núm. 44, 1987/4.

-Castellanos, Alfredo, La Cisplatina y la independencia y la república caudillesca (1817-1838), Ediciones de la Banda Orientat, Montevideo, 1975 (Historia uruguaya III).

-Cavarozzi, Marcelo, "La crisis del orden oligárquico y la constitución del Estado burgués en América Latina", trabajo pre. sentado en el Congreso Latinoamericano de Sociología, San Juan, Puerto Rico, 5-9 de octubre de 1981.

-Easton, David, Esquema para el análi. sis político, Amorrortu Editores, Buenos Aires, 1979.

-Enciclopedia Unuguaya, t. 1, ER/ARCA, Montevideo, 1969.

-Frega, Ana, El pluralismo uruguayo (1919-1933). Cambios sociales y política, CLAEH, Montevideo, 1987 (Serie Investigaciones, núm. 54).

-Gallo, Esequiel y Roberto Cortés Conde, La república conservadora, Paidós, Buenos Aires, 1972.

-Grossi, María, Partidos políticos y clases medias (a propósito del caso angentino), s.l., s.f. (Documento de trabajo núm. 4 , Grupo de trabajo de partidos políticos, CLACSO).

-Lanzaro, Jorge, Sindicatos y sistema político. Relaciones corporativas en el Uruguay (1940-1985), FCU, Montevideo, 1986.

-Lechener, Norbert (comp.), ¿Qué significa bacer política?, DESCO, Lima, 1982.
-Méndez Vives, E., El Uruguay de la modernización (1876-1904), Ediciones de la Banda Oriental, Montevideo, 1975 (Historia uruguaya $v$ ).

-Nahum, A., A. Coachi, A. Frega, I. Trochón, Crisis poltitica y recuperación económica (1930-1958), Ediciones de la Banda Oriental, Montevideo, 1975 (Historia Uruguaya vII).

-Nahum, Benjamín, La época batllista (1905-1929), Ediciones de la Banda Oriental, Montevideo, 1975 (Historia Uruguaya V).

-Pérez, Romeo, "Los partidos en el Uruguay moderno", en Cuadernos del CLAEH, núm. 31, 1984.

-Pivel Devoto, Juan E., Historia de la república ortental del Uruguay, 18301930, Ed. Raúl Artavageytia, Montevideo, 1945.

, Historia de los partidos políticos en el Uruguay, Tip. Altántida, Montevideo, 1943.

- Raíces coloniales de la revo. lucion oriental del.Unuguay, s.p.i., Montevideo, 1942.

-Rial, Juan, Elecciones, reglas de juego y tendencias, CIEP, Montevideo, 1984 (Cuaderno 3. Historia y Política).

-Thompson, Andrés, Los partidos politicos en America Latina, notas sobre el estado de la temática, CEDES, Buenos Aires, 1987 (Documentos de Trabajo 1. Grupo de trabajo de partidos políticos). 